日顎変形誌 Jpn. J. Jaw Deform. 12（1）: 15 23, April, 2002

\title{
オトガイ下縁形成骨片の移動に水酸アパタイト・燐酸三 カルシウム複合体補填を併用したオトガイ形成術
}

\author{
川村仁 長 坂 浩 後藤哲 \\ 勝部朝之山口晃史佐藤修一
Chin Surgery by Combined Use of Sliding Genioplasty and Implantation with Hydroxyapatite and Tricalciumphosphate Composite

Hiroshi KAWAMURA, Hiroshi NAGASAKA, SAtoshi GOTO, Tomoyuki KATSUBE, KoujI YAMAGUCHI and SHuichi SATO

\begin{abstract}
It is important, for the genioplasty, to make a plan for functional as well as aesthetic improvements because the chin includes not only influential parts of facial the balance but also attachment sites of suprahyoid and labiomental muscles.

Sliding genioplasty with little-detaching suprahyoid and labiomental muscles is useful for the correction of functional and aesthetic problems of chin deformities.

However, a bone graft may be employed in order to move a bony fragment in the anteroinferior border of a mandible, to correct chin deformities.

Porous hydroxyapatite and tricalciumphosphate composite (HAP - TCP) blocks, designed specially for
\end{abstract}

\section{緒言}

オトガイ形成術として，オトガイ下縁に形成した骨片を 移動し, 目的を達成する方法が広く用いられている ${ }^{1-3)}$ 。一 方, 人工材料をオトガイ前面に埋入することで, 目的を達 成する方法も報告されている

オトガイ部は舌骨上筋群やオトガイ筋等の付着部位でも あり，オトガイ形成術を適用する場合, これらの筋機能に ついても考慮する必要がある。すなわち, 形態的改善だけ such cases, can be substituted for a bone graft to stabilize a bony fragment and to improve the soft tissue line of the chin.

None of 17 cases in which functional genioplasty incorporating the implantation of the HAP - TCP blocks was applied, showed any abnormal clinical courses over three years of observation.

The results of histological and radiological study, which were indicated in some selected cases, substantiated the unproblematic clinical course of this treatment.

Key words : functional genioplasty（機能的オトガイ 形成術), bone substitution (骨補填剤) Porous Hydroxyapatite and Tricalciumphosphate Composite(多孔 体ヒドロキシアパタイト・リン酸三カルシウム複合体)

[Received Nov. 1, 2001]

でなく筋肉付着部位の位置的改善に伴う機能的改善をも考 慮した, いわゆる機能的オトガイ形成術について考える必 要がある ${ }^{6-10)}$ 。

オトガイ下縁に形成した骨片の筋を剝離することなく移 動するオトガイ形成術は，筋肉付着部位の位置的改善をも 期待できる方法である。この方法は，人工材料の埋入によ るオトガイ形成術より機能的オトガイ形成術として勝って いると考えられる。

しかし，オトガイ下縁形成骨片の移動を行おうとすると

東北大学大学院歯学研究科顎顔面口腔外科学講座顔面口腔外科分野 (主任 : 茂木克俊教授)

Division of Maxillofacial and Plastic Surgery,Department of Oro-Maxillofacial Surgical Science,Tohoku University Graduate School of Dentistry (Chief: Prof. Katsutoshi MOTEGI) 
き，オトガイ部の変形の程度によっては，下顎骨と移動骨 片との間に大きな段差や間隙を生ずる場合がある。それを 補うために骨移植が行われている ${ }^{11,12)}$

しかし，このような役割であ机ば，骨補填材である多孔

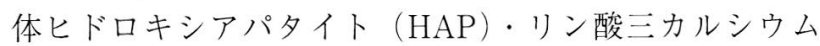
(TCP)（以後，HAP · TCP と略す）ブロックの代用が可 能と考えられ, HAP · TCP ブロックを本法専用にデザイ ンし適用したところ, 良好な結果を得たので, 術式の概要 と適用症例の術後の安定性について報告する。

\section{オトガイ用多孔体 HAP・TCP ブロック}

今回，われわれが用いた多孔体 HAP・TCP ブロックは 気孔率 35\%, 気孔径 5 15 $\mu \mathrm{m}$ の多孔体セラタイト（日 本特殊陶業株式会社）である。

まず，オトガイ形成術の適用が必要と診断された重度の 小下顎症で，オトガイ下縁に形成された骨片を適切なとこ ろへ移動したときに，下顎骨への接触が殆ど無くなると考 えられた一症例を選択した。この症例の三次元 CT データ から得られた光造形モデルを利用し，オトガイ下縁の形成 骨片を移動するオトガイ形成術に準じたモデルサージェリー を行った。形成された下縁骨片に相当する部分を適切な位 置 $(10 \mathrm{~mm}$ 前方) へ移動した結果，前方移動片の下顎骨体 側との接触が非常に少なくなっただけでなく，下顎骨体側 との間に大きな段差を生じた。その段差を埋めながら移動 片を安定させるための人工骨による望ましい補填状態を,

ワックス充填により検討した（Fig. 1)。

そして，望ましい補填状態を示すワックスの形に近似す
るように整形した，多孔体 HAP ・ TCP ブロックを作製し た (Fig. 2)。

HAP ・ TCP ブロックは，正中部で分割しそれぞれを右 側用，左側用と，左右別々に扱えるようにし，様々なオ卜 ガイ部の形態に対しても容易に適合できるようにした。さ らに，下縁骨片を非対称に移動することで，下顎骨体との 間に生ずる非対称な段差に対しても，片側だけの適用を可 能とした。

埋入時にオトガイ神経脈管を保護するために，HAP · TCP ブロックの形の微修正を必要とする症例もあったが, 多孔体 HAP · TCP の形態の微修正は, 術中に小刀やスチー ルバー等を利用し，容易に行うことができた。

\section{オトガイ下縁形成骨片の移動と多孔体 HAP ・ TCP ブロックを併用する機能的オトガイ形成術}

頭部 X 線規格写真等でオトガイ変形の程度を評価し， それを改善するために必要なオトガイ下縁形成骨片の移動 量と移動様相を予測する。CT データを利用した光造形モ デルを用意することが可能であれば，予測はより容易であ る。予測に併せて HAP・TCP ブロックの必要の有無を決 定する。移動骨片が母床骨と十分な接触を保っているので あれば，骨片の前方移動量が 7 ～ $8 \mathrm{~mm}$ でも， HAP · TCP ブロックの併用は不要と考えている。しかし，この程度の 移動でも，移動骨片が下顎骨体へ十分な接触を獲得できな いときは，多孔体 HAP · TCP ブロックの併用を考える。 また，移動骨片を左右非対称に前方へ移動するとき，前方 移動量の多い方に HAP · TCP ブロックを補填することで,
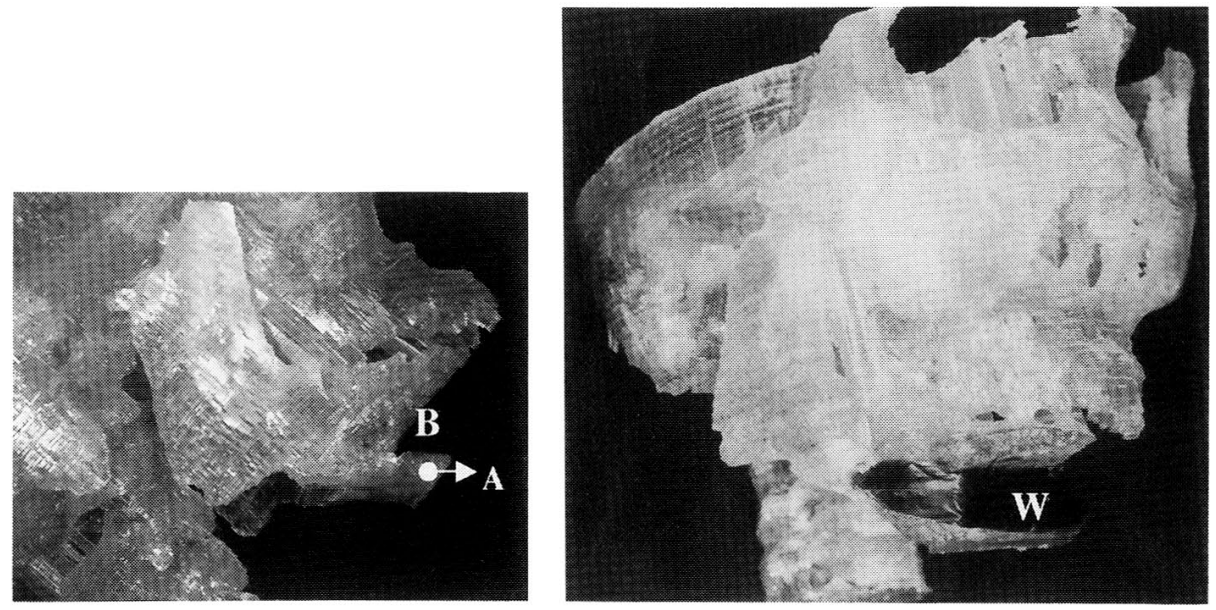

Fig. 1 Prediction of the shape of HAP - TCP blocks to support sliding genioplasty by filling wax (W) over the step.

A: The inferoanterior border segment of mandible advanced large.

B: A little bone contact and a large step between proximal and distal segments followed by large advancement of the inferoanterior border segment of mandible. 

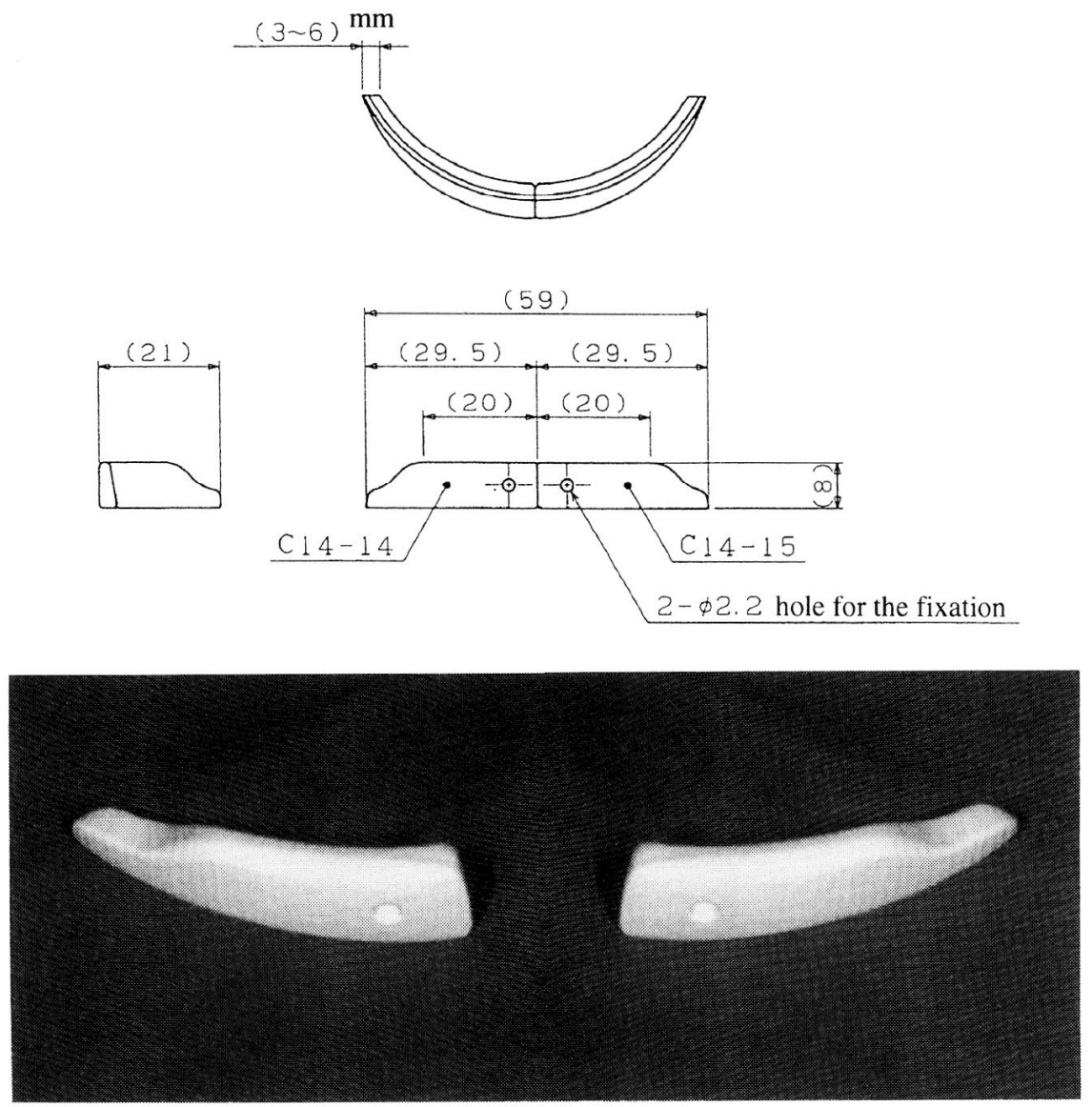

Fig. 2 Drawing and porous HAP - TCP blocks designed specially to support sliding genioplaty.

軟組織形態の良好な改善を期待できる場合が少なくない。 オトガイ部を垂直的に延長するための，形成骨片の下方移 動で生ずる隙間は，小さい場合でも補填が望ましい。

オトガイ下縁骨片の形成法としての, 粘膜骨膜弁の形成 や骨切離術はすでに報告したごとくであり ${ }^{10)}$ ，移動骨片に できるだけ広く軟組織が温存される様につとめる。移動骨 片を計画した位置にボーンスクリュウやボーンプレートで 固定し, 移動骨片と下顎骨との間に生じた段差や隙間を, HAP ・ TCP ブロックでオンレイ的に補填する。

埋入した HAP・TCP ブロックもボーンスクリュウで下 顎骨体に固定する（Fig. 3)。粘膜骨膜弁を戻し，創を閉 鎖し手術を終了する。

\section{手術後の安定性の検討}

1）検討対象症例

この方法を適用し 3 年以上を経過した 17 例について, 臨床評価を行った。その中で, X 線資料のそろっていた 9 例について X 線学的評価も行った。

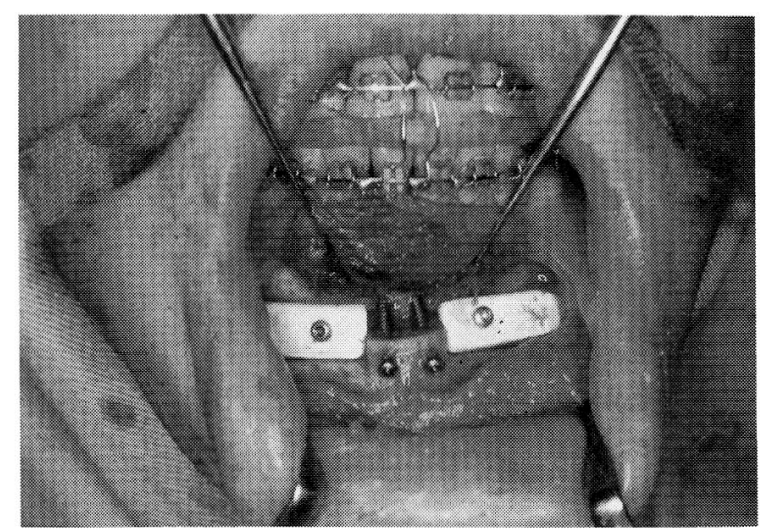

Fig. 3 Sliding Genioplasty using a broad soft tissue pedicle and supported with porous HAP $\cdot$ TCP blocks.

性別は男性 5 名, 女性 12 名で, 手術時の年齢は 18 歳か ら 32 歳, 平均土標準偏差が $24.0 \pm 3.7$ 歳であった。 オトガイ形成術は, 全て他の顎矯正手術と同時に施行さ 


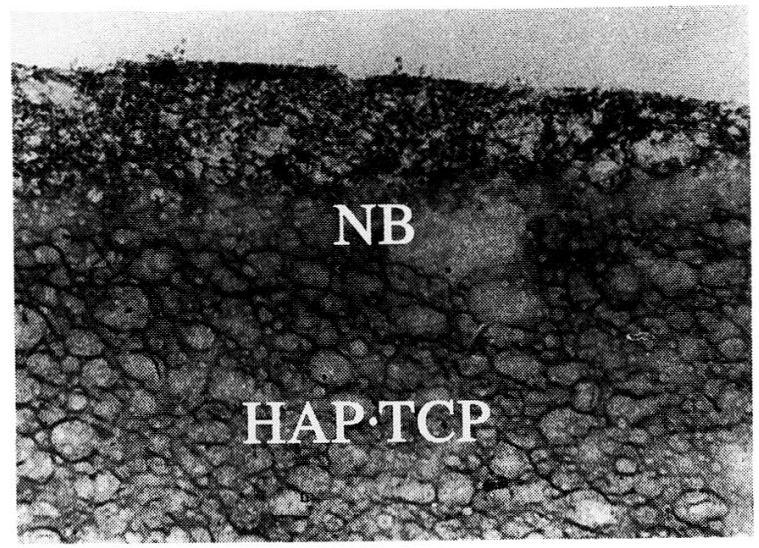

Fig. 4 Histologic section of the biopsy sample which was taken from the HAP . TCP blocks implanted to support advanced inferoanterior border fragment of mandible (NB; new bone, H\&E $\times 132)$.

れていた。オトガイ下縁形成骨片は，一例をのぞき，全て 下顎骨と接触を保ちながら前方へ移動され, 術直後の側方 頭部 X 線規格写真上で水平的（FH 平面に平行）に 7 から $13 \mathrm{~mm}$ 前方に移動されていた。1 例は水平的に前方へ 6 $\mathrm{mm}$ ，垂直的（ $\mathrm{FH}$ 平面に垂直）に下方へ $4 \mathrm{~mm}$ 移動され， 下顎骨との接触が失われ, 移動骨片と軟組織形態を安定さ せるためにこの方法が適用されていた。

2) 臨床評価

今日まで，臨床経過に異常を示した症例は 1 例もなかっ た。 5 例で, 臨床経過に何ら問題を認めないものの患者の 希望により，ボーンプレートやボーンスクリュウの除去術 が行われた。除去術の時期は, 全て埋入後 1 年以上を経過 していた。その時の手術所見として，HAP - TCP 周囲に 異常を認めなかった。また，除去術時に，患者の了解を得 て HAP ・ TCP の一部を標本とし，組織検査を行った。そ の結果, HAP ・ TCP ブロック表面を覆う骨の新生が確認 され，周囲に炎症細胞の浸潤はほとんどみられず，骨への 親和性を保ちつつ安定した状態で埋入されていると考えら れた（Fig. 4)。

3）側方頭部 X 線規格写真による評価

(1) 分析方法

観察時期を術前, 術直後, 術後 1 年, 術後 3 年以上経過 時の 4 時期とした。

術前の側方頭部 X 線規格写真上で Pogonion を原点と L $\mathrm{FH}$ 平面に平行な線を $\mathrm{X}$ 軸，原点を通り $\mathrm{X}$ 軸に直交す る線を $\mathrm{Y}$ 軸とする XY 座標を定めた。

各時期に撮影された側方頭部 $X$ 線規格写真を下顎中切 歯歯槽骨の舌側骨梁と下顎骨下縁で, best fit 法により重

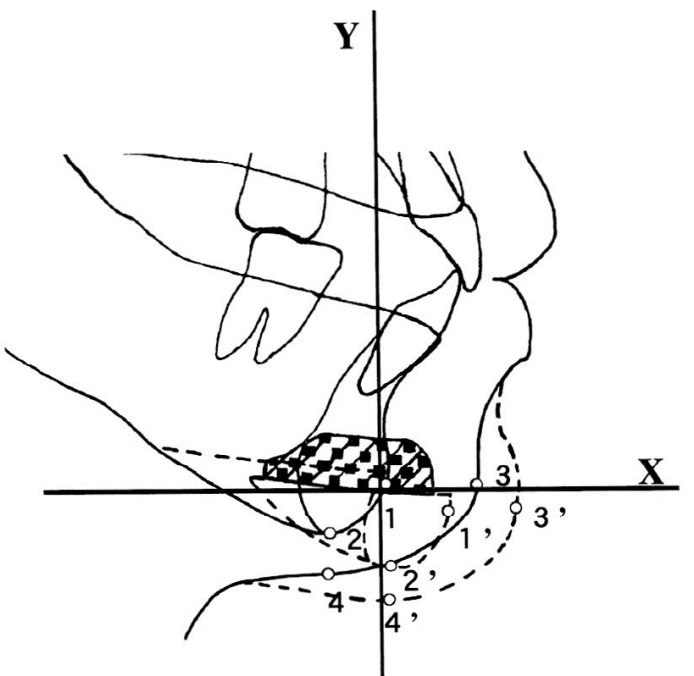

1: Pogonion (Pog)

1': Postoperative Pog

2: Menton (Me)

2': Postoperative Me

3: Point of soft tissue pogonion (SPog)

3': Postoperative SPog

4: Point of soft tissue menton (SMe)

4’: Postoperative SMe

Fig. 5 Landmarks in the pre- and postoperative chins of the cephalograms superimposed on mandibular plane and lingual surface of the symphyses.

ね合わせ，各時期の Fig. 5 に示す計測点について，術前 から術直後, 術後 1 年経過時, 術後 3 年以上経過時までの XY 方向の変化量を求め評価した。

(2) 結果

Fig. 6 は，骨接触を保ちつつ形成骨片が移動された 8 例の, 術前からの各時期における硬軟組織の，X および $\mathrm{Y}$ 軸方向の変化量の平均土標準偏差を示す。

オトガイ下縁に形成された骨は，手術により平均で Pog が $9.1 \pm 1.9 \mathrm{~mm}, \mathrm{Me}$ が $8.7 \pm 2.2 \mathrm{~mm}$ 前方へ，それに伴い Spogは $8.3 \pm 2.1 \mathrm{~mm}(91 \%), \quad \mathrm{SMe}$ は $8.7 \pm 2.2$ (100\%) の割合で前方へ移動されていた。下方への移動はPog が $1.8 \pm 2.5 \mathrm{~mm}, \mathrm{Me}$ が $1.3 \pm 2.3 \mathrm{~mm}$ に対して Spog が $1.8 \pm$ $2.5 \mathrm{~mm}(100 \%), \mathrm{SMe}$ が $0.2 \pm 3.3 \mathrm{~mm}$ (17\%) であった。 そして，それらの位置は，術後 1 年， 3 年以上の経過時 点で，すべて $0.5 \mathrm{~mm}$ 未満の変化にとどまっていた。術前 から各観察時期までの変化に，ステューデントの $\mathrm{t}$ 検定を 用いて検討した結果，統計的有意な差を認めなかった。

Fig. 7 は形成骨片を前下方に移動した結果，形成骨片 と下顎骨体との間の骨接触が完全に失われた 1 例の，硬軟 組織の変化を示す。手術により Pog が前方に $6.7 \mathrm{~mm}$ 下方 に $4.2 \mathrm{~mm}$, Meが前方に $6.0 \mathrm{~mm}$ 下方に $3.5 \mathrm{~mm}$ 移動され， 


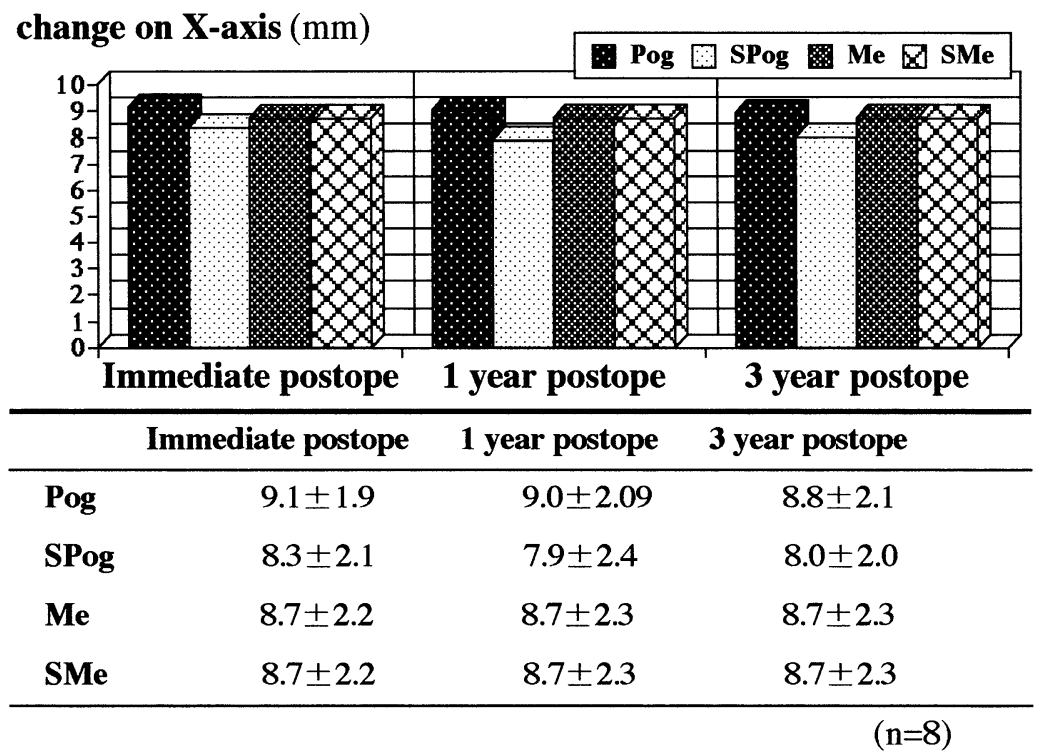

change on $\mathbf{Y}$-axis $(\mathrm{mm})$

Immediate postope 1 year postope 3 year postope

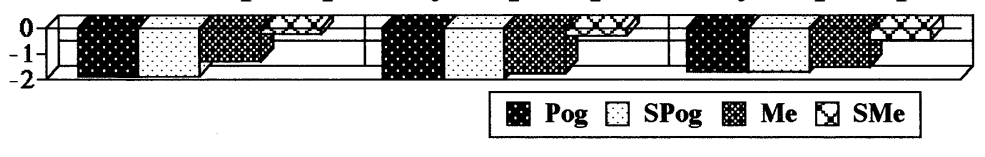

\begin{tabular}{|c|c|c|c|}
\hline & Immediate postope & 1 year postope & 3 year postope \\
\hline Pog & $-1.8 \pm 2.5$ & $-2.0 \pm 2.6$ & $-1.7 \pm 2.5$ \\
\hline SPog & $-1.8 \pm 2.5$ & $-2.0 \pm 2.6$ & $-1.7 \pm 2.5$ \\
\hline Me & $-1.3 \pm 2.3$ & $-1.7 \pm 2.4$ & $-1.5 \pm 2.3$ \\
\hline SMe & $-0.2 \pm 3.3$ & $-0.3 \pm 4.0$ & $-0.5 \pm 3.2$ \\
\hline
\end{tabular}

Fig. 6 The immediate, 1 year and 3 year postoperative average changs of advanced inferoanterior border segment of mandible at Pog, SPog, Me, and $\mathrm{SMe}$ on $\mathrm{X}$-axis and $\mathrm{Y}$-axis in 8 cases.

The each value indicated the change from the preoperative point to the immediate, 1 year, and 3 year postoperative point.

SPog が前方に $4.7 \mathrm{~mm}(71 \%), \mathrm{SMe}$ が $6.0 \mathrm{~mm}(100 \%)$, 下方に SPog が $4.2 \mathrm{~mm}(100 \%)$, SMe が $5.4 \mathrm{~mm}$ (155\%) の割合で移動された。そして，それらの位置は，SMeた けが術後 1 年までに垂直的に約 $2 \mathrm{~mm}$ の後戻り変化を示し たものの，他は $1 \mathrm{~mm}$ 以内の変化であった。

Fig. 8 はこの症例の術前と術後 3 年経過時の顔貌の変 化とセファログラムの重ね合わせを示す。

\section{考察}

1）オトガイ形成術の選択について
オトガイ形成術は，オトガイ下縁に形成した小骨片の移 動による方法と人工材料の埋入による方法がある。 Guyuron ら ${ }^{13}$ はこの二つの方法を比較する中で, 骨形成 術の方が軟組織形態の変化を, より予測し易いとし, 特に 頸部からオトガイにかけての曲線の改善で優れていると報 告している。

オトガイ部は，口角下制筋，下唇下制筋，オトガイ筋， そして顎二腹筋, オトガイ舌骨筋, オトガイ舌筋等が付着 し，口唇周囲の運動機能や舌の運動機能に重要な役割を担っ ている。同部の変形はこれらの筋肉の付着部位にも変位が 


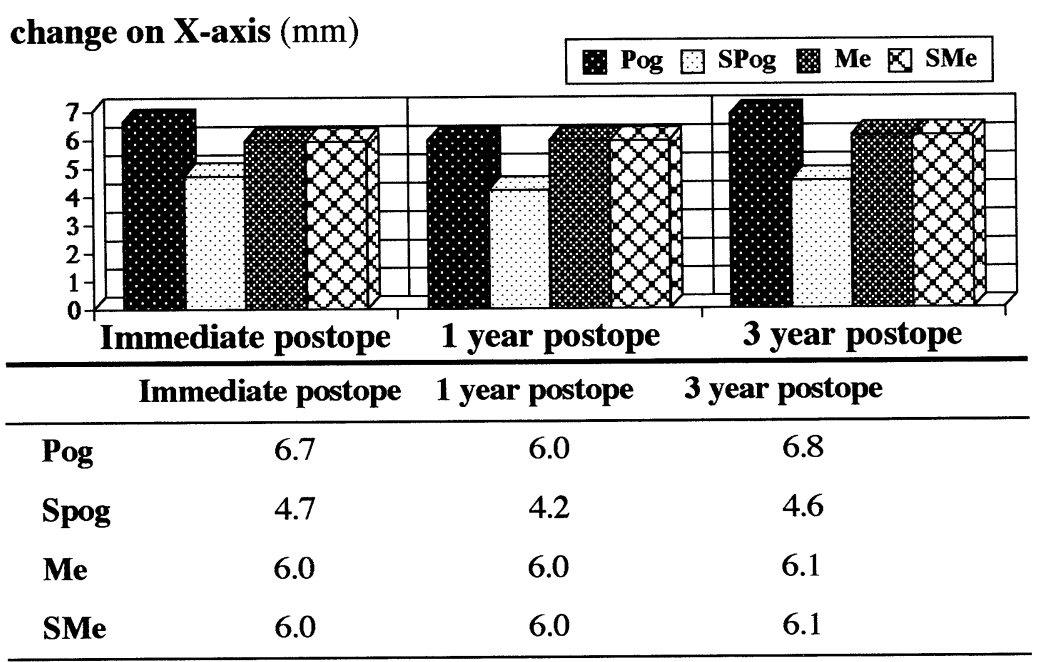

change on $\mathbf{Y}$-axis $(\mathrm{mm})$

Immediate postope 1 year postope 3 year postope

\begin{tabular}{|c|c|c|c|}
\hline Pog & -4.2 & -4.9 & -4.6 \\
\hline SPog & -4.2 & -4.9 & -4.6 \\
\hline Me & -3.5 & -3.7 & -3.3 \\
\hline SMe & -5.4 & -3.3 & -2.6 \\
\hline
\end{tabular}

Fig. 7 The immediate, 1 year and 3 year postoperative changes of advanced inferoanterior border fragment of mandible at Pog, SPog, Me, and $\mathrm{SMe}$ on $\mathrm{X}$-axis and $\mathrm{Y}$-axis in the case.

The each value indicated the change from the preoperative point to the immediate, 1 year, and 3 year postoperative point.

生じていることを意味し, 機能的問題も合併していると考 えられる。従って，オトガイ形成術を計画するとき，この 点に配慮することも重要であり, 機能的オトガイ形成術と して計面立案することが大切である ${ }^{10,14,15)}$ 。

変形の程度が少ないとき, 手術侵襲の軽減から人工材料 による方法を選択されることが，否定されるべきではない。 しかし, 変形が重度であればあるほど, 審美的問題だけで なく機能的問題も重度であり, 機能的オトガイ形成術の計 画が重要となってくる。

私たちは，オトガイ形成術の適応例に対して，オトガイ 下縁に形成した骨片を適正な位置に移動する方法を第 1 選
択としている。骨形成術としては，Bell らの報告した broad soft tissue pedicle genioplasty ${ }^{16,17)}$ 基本として いる。すなわち, 形成骨片の筋肉付着部を剝離しないよう にすることで，骨片移動に伴う筋付着部位の位置的改善を 計るだけでなく移動骨片への血液供給路を広く温存し, 安 定した骨性治癒も計っている ${ }^{10,18)}$ 。

しかし, 重度のオトガイ变形の改善を目的として形成骨 片を移動しようとするとき, 移動骨片の母床骨側への接触 が非常に少なくなる場合や完全に失われる場合がある。こ の状態で, ボーンプレートやボーンスクリュウによる骨片 固定を適用したとしても，骨癒合の不十分や下顎骨と移動 

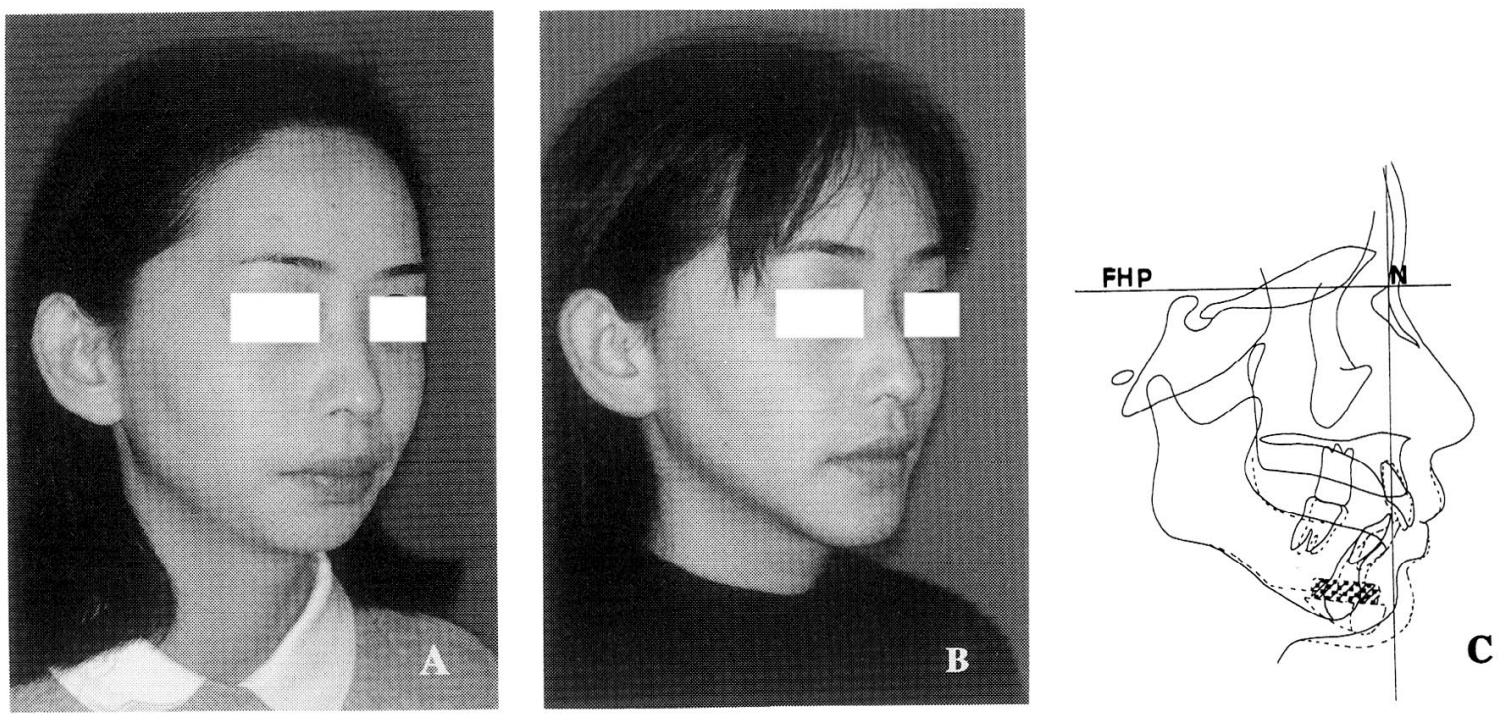

Fig. 8 Pre- (A) and 3 year postoperative (B) facial views and superimposition of pre- and 3 year postoperative cephalograms (C) on FH plane at Nasion in the case that inferoanterior border fragment of mandible was moved forward and downward without bone contact and supported by the HAP - TCP blocks in.

形成骨片との間に生ずる大きな段差や間隙への軟組織の嵌 入による軟組織形態改善の不十分が予測され，これを防ぐ ために自家骨移植が選択されている11122。

オトガイ下縁形成骨片移動に骨移植を併用する場合，形 成骨片を前方移動することで生じた大きな段差をなだらか にするように，骨表面にチップ状のものを填入する場合と， 垂直的に延長するために形成骨片を下方移動することで生 ずる下顎骨との間の間隙にブロック状のものを挟む方法が 行われている ${ }^{11,12) 。 ~}$

しかし，自家骨移植を実施する場合，骨採取のための新 たな侵襲が生ずるだけでなく，移植骨の吸収による術後の 安定性に疑問が生ずる。

オトガイ形成術として人工材料のみによるオトガイ部の 増量術でよい結果を報告しているものもあるが19), オトガ イ内面の筋の付着部位の位置的改善ができないだけでな く,インプラント下面の骨吸収が観察されるとの報告もあ る $^{20,211}$ 。

一方，オトガイ下縁形成骨片の移動と人工材料との併用 例の報告もみられる。Rosen ${ }^{22}$ はオイガイ部の垂直的延長 を目的として，オトガイ形成骨片と母床骨との間に自家骨 移植では安定性に疑問があるとし，ヒドロキシアパタイト を埋入することで良好な結果を得たとしている。Scharoff $ら^{233}$ は形成骨片の移動のみでは改善が不十分と考えられた とき，補足的にシリコンゲルを用いることで，良好な結果 が得られただけでなく自家骨採取をさける利点があったと
している。Zeller ら ${ }^{24}$ はオトガイの前方移動と垂直的延長 のために，前もって整形した緻密体のヒドロキシアパタイ トブロックの利用について報告し, オトガイの前方移動を 伴わない垂直的延長はまれであるが，このようなとき緻密 タイプのヒドロキシアパタイトブロックを利用することで 骨移植はさけられるとしている。

われわれは，オトガイ下縁を前方移動することなく垂直 方向にのみ延ばす症例を経験していない。従って, 移動し た形成骨片の上面から下顎骨体側の前面にオンレイ的に人 工骨を補填することで，骨移植の代用を計った（Fig. 1)。 このような人工骨の使い方で移動骨片を安定させるために は，顆粒状のものよりブロックタイプの方が確実であると 考えた。また，人工骨に支えられる軟組織形態の改善予測 もブロックタイプが容易と判断し, 多孔体 HAP ・ TCP ブ ロックタイプを選択し，骨移植を行うことなく良好な結果 を得た。

2）オトガイ形成のための人工材料について

オトガイ形成のための人工材料として Proplast, Polyethylen，Silicon，などを利用する報告もみられるが，最 近ではヒドロキシアパタイトを利用する報告が多い、19.22,20-27)。 ヒドロキシアパタイトの数多くの研究は，ヒドロキシアパ タイトが骨伝導能を有し，骨に対する親和性が非常に高い 有用な骨補填剂であることを示した28)。リン酸三カルシウ ム (TCP) も骨補填材のひとつであるが, HAP も TCP も 優れた骨親和性を有するものの機械的強度に欠点を有する 
とされている。しかし，HAP と TCP の複合体とすること で優れた骨親和性を保ったまま高い強度の骨補填材とする ことに成功した299。

多孔体 HAP ・ TCP ブロックを臨床応用した今回のわれ われの症例において, 患者の同意を得て, 埋入した HAP . TCP の一部分を採取し組織学的検討を 5 例で行った。そ の結果も, 多孔体 HAP ・ TCP ブロックが骨伝導能を有し 骨親和性が高い骨補填剤のひとつであることを示唆するも のであった。

HAP · TCP は多孔体と緻密体とが用意され, 多孔体は 強度的に劣っているものの加工が容易であるという利点を 有している。本法における骨補填材の利用は自家骨移植に 代わり，移動骨片が下顎骨に骨癒合するまで骨片を安定さ せるとともに骨瘉合の促進を計り，また良好な軟組織形態 の改善をもサポートすることである。このような利用とし ては緻密体ほどの強度を必要とせず, 多孔体 HAP · TCP で十分と考えられた。オトガイ形態は個体により全て異なっ ているわけで，個体に合わせた微調整が必要と考えられ， この点からも微調整が容易な多孔体 HAP - TCP の選択と なった。

術後の安定性についての X 線学的検討結果は, この選 択を支持するものであった。

$\mathrm{HAP}$ ・ TCP ブロックを利用するとき，適用部位によっ ては，その形態を予測し整形した状態で提供されている。 オトガイ部の人工材料による増量術でも，オトガイ用とし て前もって整形されたものを用意している場合がみられ る ${ }^{19,24)}$ 。本法でのオトガイ形態の改善は形成骨片の移動に よるのが基本であり，HAP・TCP ブロックの役割は補助 である。従って，その形態は比較的単純なものにできると 考えた。すなわち, 本法が適用されると考えられる一症例 を選択し，その光造形モデル上で HAP - TCP による補填 形態を予測し，それに基づいて右側用，左側用のそれぞれ を作製した。そして，これまでの適用例のほとんどは，こ れをそれぞれ一個ずつ適用することで十分であった。しか し，少数例ではあったがさらに補填する必要を生じた症例 もみられた。このときは 2 枚重ねとし適用することで役割 を達成することができた。

3）本法適用例の術後安定性について

本法適用例の術後の安定性についての分析結果は, 術直 後から術後 1 年の間で軟組織形態に若干の変化を認めたも のの, 術後の腫脹を考慮するならば納得できる範囲と考え られた。すなわち, 分析結果は, 本法の適用による移動骨 片の安定性, 軟組織形態改善の安定性とも十分満足できる ことを示した。

しかし，本法適用による機能的改善の安定性についての
評価は困難であり，この点についての検討がさらに必要で ある。また，多孔体 HAP ・ TCP ブロックは，完全に骨と 置換されるわけではない。この点についても, 慎重に経過 観察し，長期的検討を行う必要がある。

\section{結 論}

オトガイ形成術として，オトガイ下縁に形成した骨片に できるだけ広範囲に軟組織を付着させたまま移動する方法 を適用するとき, 移動骨片の移動の程度によっては, 下顎 骨との接触不十分や軟組織形態の改善不十分が生じやすい。 それを防止するために，多孔体 HAP ・ TCP ブロックを適 用したところ，自家骨移植を必要とすることなく良好な結 果が得られた。

比較的長期の経過観察結果でも多孔体 HAP ・ TCP ブロッ ク埋入に伴う異常を認めず，移動形成骨片も軟組織形態も 安定していることが確認された。

\section{引用文献}

1) Trauner, R.T., et al.: The surgical correction of mandibular prognathism and retrognathia with consideration of genioplasty. Part I. Surgical procedures to correct mandibular prognthism and reshaping of the chin, Oral Surg, $10: 677-689$, 1957.

2) Scheideman, G. B., et al.: Soft tissue changes with combined mandibular setback and advancement genioplasty, J Oral Surg 39 : 505-509, 1981.

3) Ellis, E. 3d. et al.: Advancement genioplasty with and without soft tissue pedicle: An experimental investigation, J Oral Maxillofac Surg, 42 : 637645, 1984.

4) Dann, J. J., et al.: Proplast genioplasty: a retrospective study with treatment recommendations, Angle Orthod, 47 : 173-185, 1977.

5) Karras, S. C., et al.: Augmentation genioplasty with hard tissue replacement implants, J Oral Maxillofac Surg, 56 : 549-552, 1998.

6) Precious, D. S., et al.: Correction of anterior mandibular vertical excess: the functional genioplasty, Oral Surg, 59 : 229-235, 1985.

7) Schendel, S. A : Genioplasty: a physiological approach, Annals of Plastic Surgery, 14 : 506-514, 1985.

8) Alvarez, C., et al.: Mandibular advancement combined with horizontal advancement genioplasty for the treatment of obstructive sleep apnea in an edentulous patient. A case report, Oral Surg, 64 : 402-406, 1987.

9) Hookey, S. R., et al.: New developments in genioplasty: functional versus cosmetic, Aust Orthod J, $11: 2-6,1989$.

10）川村 仁，他：機能的オトガイ形成術（functional 
genioplasty）によるオトガイ変形の改善, 日顎変形 誌, $7: 69-78,1997$.

11) Bell, W.H., et al.: Surgical Correction of Dentogacial Deformities. Vol 2. 1st Ed, W.B. Sounders Co, Philadelphia, 1980, p 1210-1279.

12) Proffit, W.R., et al.: Surgical Orthodontic Treatment, $1^{\text {st }}$ Ed, Mosby Year Book, St Louis, 1991, p 300-306.

13) Guyuron, B., et al.: A critical comparison of osteoplastic and alloplastic augmentation genioplasty, Aesthetic Plastic Surger, 14 : $199-$ 206, 1990

14) Precious, D.S., et al: Correction of anterior mandibular vertical excess: The functional genioplasty, Oral Surf, 59 : 229-235, 1985.

15) Hookey, S. R., et al.: New developments in genioplasty: functional versus cosmetic, Aust Orthod J, $11: 3-6,1989$.

16) Bell, W. H., et al.: The versatility of genioplasty using a broad pedicle, J Oral Maxillofac Surg, $41: 763-769,1983$.

17) Bell, W.H.: Surgical Correction of Dentofacial Deformities: New concept, vol 3, 1st Ed, W.B. Sounders Co, Philadelphia, 1985, p 57-70.

18）佐藤修一，他：広範囲に軟組織を付着させるオトガイ 形成術適用後の術後変化一頭部 X 線規格写真による 評価一，日顎変形誌，2：19-24，1992.

19) Karras, S. C., et al.: Augmentation genioplasty with hard tissue replacement implants, J Oral Maxillofac Surg, 56 : 549-552, 1998.

20) Matarasso, A., et al.: Labial incompetence: a marker for progressive bone resorption in silastic chin augmentation, Plast Reconstr Surg, 98 : 1007-1014, 1996.

21) Robinson, M., et al.: Bone resorption under plastic chin implants, J Oral Surg, 27: 116$118,1969$.

22) Rosen, H. M.: Surgical correction of the vertically deficient chin, Plastic \& Reconstructive Surgery, 82 : 247-256, 1988.

23) Sclaroff, A., et al.: Augmentation genioplasty : when bone is not enough, American Journal of Otolaryngology, $13:$ 105-108, 1992.

24) Zeller, S. D., et al.: Use of preformed hydroxylapatite blocks for grafting in genioplasty procedures, Int J Oral Maxillofac Surg, 15 : 665-668, 1986.

25) Dann, J. J., et al.: Proplast genioplasty : a retrospective study with treatment recommendations, Angle Orthod, 47 : 173-185, 1977.

26) Shaber, E. P.: Vertical interpositional augmentation genioplasty with porous polyethylene, Int $\mathrm{J}$ Oral Maxillofac Surgery, 16 : 678-681, 1987.

27) Wolford, L. M., et al.: Coralline porous hydroxyapatite as a bone graft substitute in orthognathic surgery, J Oral maxillofac Surg, 45 : 1034-1042, 1987.

28) Holmes, R. E. : Bone regeneration within a coralline hydroxyapatite implant, Plast Reconstr Surg, $63:$ 626-633, 1979.

29) Kondo, K., et al.: Preparation of high-strength apatite ceramics, Am. Ceram. Soc, 67 : C222-C223, 1984. 